\title{
Patterns of nuclear fluorescence and DNA-binding activity
}

\author{
ANTHONY LUCIANO AND NAOMI F. ROTHFIELD \\ From the Department of Medicine, School of Medicine, University of Connecticut, Farmington, Conn., and \\ the Newington Veterans Administration Hospital, Newington, Conn.
}

Sera from patients with systemic lupus erythematosus (SLE) and other connective tissue diseases have been demonstrated to contain a variety of antinuclear antibodies. Antibodies to native DNA appear to be present only in sera from patients with clinically active SLE. These antibodies have been detected by a variety of techniques, such as precipitation in agar (Seligmann, 1957), complement fixation (Ceppellini, Polli, and Celada, 1957; Robbins, Holman, Deicher and Kunkel, 1957), immunofluorescence (Friou, Finch and Detre, 1958), and, more recently by the Farr ammonium sulphate precipitation technique (Wold, Young, Tan, and Farr, 1968; Pincus, Schur, Rose, Decker, and Talal, 1969; Hughes, Cohen, and Christian, 1971 ; Carr, Koffler, Agnello, and Kunkel, 1969).

At the present time, the laboratory test used most widely in the diagnosis of SLE is the indirect fluorescent antibody test (ANA) in which a source of whole nuclei is used. This technique is extremely sensitive and capable of detecting all antibodies which are directed against nuclear antigens. A variety of patterns of nuclear fluorescence may be observed, such as speckles, diffuse fluorescence of the entire nucleus, and fluorescence of the periphery of the nucleus. The peripheral pattern seems to be limited to sera from patients with clinically active SLE (Casals, Friou, and Teague, 1963; Gonzalez and Rothfield, 1966), the diffuse pattern is commonly observed in sera from inactive SLE patients and patients with rheumatoid arthritis (Gonzalez and Rothfield, 1966; Hughes and Rothfield, 1970), and the speckled pattern is found most frequently in sera from patients with progressive systemic sclerosis (Rothfield and Rodnan, 1968). In addition, sera from elderly individuals and a small percentage of normal subjects may produce either a diffuse or a speckled pattern (Rothfield and Rodnan, 1968; Cammarata, Rodnan, and Fennell, 1967).
We have previously analysed sera from patients with SLE and demonstrated that complement-fixing antibodies to native DNA or to the DNA of the DNAhistone complex are present in sera which produce a peripheral pattern of nuclear fluorescence (Rothfield and Stollar, 1967).

The present study was performed in an attempt to correlate the pattern of nuclear fluorescence obtained by the indirect fluorescent antibody technique with the level of anti-DNA antibodies obtained by the Farr ammonium-sulphate technique and to evaluate the usefulness of the two methods in the diagnosis and management of patients with SLE.

\section{Materials and methods}

\section{PATIENTS}

Sera were studied from patients seen at the UniversityMcCook Hospital, the Newington Children's Hospital, Hartford Hospital, New Britain General Hospital, St. Francis Hospital, and Mt. Sinai Hospital. 158 sera were studied from 82 SLE patients in whom the duration of disease ranged from 1 month to 15 years. All had evidence of multiple system disease compatible with SLE and a positive LE-cell preparation at some time during the course of the disease, and fitted the preliminary criteria for the diagnosis of SLE (Cohen, Reynolds, Franklin, Kulka, Ropes, Shulman, and Wallace, 1971). The clinical disease activity was graded from zero (complete remission with or without therapy) to $3+$. Sera from 92 patients with juvenile rheumatoid arthritis (JRA), forty patients with definite or classical rheumatoid arthritis (RA), forty patients with progressive systemic sclerosis, sixty patients with pulmonary tuberculosis, and ninety normal individuals were studied.

PREPARATION OF RADIOACTIVE DNA

Tritium-labelled DNA was prepare 1 from a thymine minus strain of $E$. Coli K12. The cells were grown in M9 glucose medium containing 1 per cent. casamino acids, $25 \mu \mathrm{g}$, per ml. tryptophane, $0 \cdot 2$ per cent. glucose, and $3 \mu \mathrm{g}$. per $\mathrm{ml}$. thymidine, then diluted 1:100 and grown overnight in the 
same medium without thymidine to deplete endogenous pools of thymidine. After diluting again 1:100, the cells were grown to O.D.650 $=0.025$. The cells were exposed to $1.0 \mu \mathrm{c} . / \mathrm{ml} .\left({ }^{3} \mathrm{H}\right)$ thymidine (specific activity $6.7 \mathrm{c} . / \mathrm{mmol}$.) at $37^{\circ} \mathrm{C}$. and allowed to grow to the stationary phase. Cells were harvested by centrifugation, washed once with $100 \mathrm{ml}$. $0.15 \mathrm{M}$ saline and re-suspended in $5 \mathrm{ml} .0 .01 \mathrm{M}$ tris $\mathrm{HCl}$ buffer (pH 7.5) containing $0.75 \mathrm{M}$ sucrose. $0.6 \mathrm{ml}$. of a lysozyme solution $(1 \mathrm{mg}$. per $\mathrm{ml}$. in $0 \cdot 1$ tris $\mathrm{HCl}$ buffer, pH 7.5) and $12 \mathrm{ml}$. of $0.0015 \mathrm{M}$ EDTA, pH 8, were added and the mixture was incubated at $37^{\circ} \mathrm{C}$. for $15 \mathrm{~min}$. $1.8 \mathrm{mg}$. pronase and $0.24 \mathrm{ml} .40$ per cent. sodium dodecyl sarcosinate were added to lyse the cells. After incubation at $37^{\circ} \mathrm{C}$. for $60 \mathrm{~min} ., 10.7 \mathrm{~g}$. caesium chloride were added to the lysate. Four ml. of the mixture were transferred into each of six tubes containing $8.0 \mathrm{ml}$. of 60 per cent. caesium chloride in $0.01 \mathrm{M}$ tris $\mathrm{HCl}$ buffer, $\mathrm{pH} 7.5$. The final concentration of caesium chloride in the tubes was $1.7 \mathrm{~g} . / \mathrm{cm} .^{3}$ The tubes were centrifuged at $20^{\circ} \mathrm{C}$. for $45 \mathrm{hrs}$ at 33,000 r.p.m. using SW41 rotor. The DNA, which appeared as a sharp band in the middle of the tube, was withdrawn, and dialysed against saline citrate buffer, $\mathrm{pH} 7 \cdot 0$, for $24 \mathrm{hrs}$. The final volume of DNA solution recovered was $20 \mathrm{ml}$. containing $0.3 \mathrm{mg}$. DNA per $\mathrm{ml}$. The specific activity was $4.35 \times 10^{7}$ counts per minute per $\mu \mathrm{g}$. DNA or $1.3 \times 10^{7}$ c.p.m. per ml. of DNA solution. The concentrations of DNA and protein were determined by the ratio of absorbance at optical density 260 and 280 and the Folin reaction. The native DNA was free of protein.

AMMONIUM-SULPHATE PRECIPITATION TECHNIQUE The amount of labelled DNA bound by the serum to be tested was determined by the method of Wold and others (1968), using $0.05 \mathrm{ml}$. serum diluted to $5 \mathrm{ml}$. in $0.1 \mathrm{M}$ borate saline buffer, $\mathrm{pH} 8.0$, and $0.5 \mathrm{ml}$. labelled DNA solution diluted to $0.0015 \mathrm{mg}$. DNA per ml. All sera were tested in duplicate. The DNA-binding activity is expressed as the counts per minute in the precipitate of test serum less the counts per minute precipitated by normal serum divided by total counts in the DNA $\times 100$.

INDIRECT FLUORESCENT ANTIBODY TEST FOR ANA The test was carried out as previously described using mouse liver as a source of nuclei and fluorescein isothiocyanate labelled anti-IgG (Gonzalez and Rothfield, 1966). Sera were tested undiluted and the pattern of nuclear fluorescence recorded. The sera were studied without knowledge of the results of the ammonium-sulphate technique.

\section{Results}

\section{DNA-BINDING}

The results of the ammonium-sulphate technique for DNA-binding is shown in Fig. 1. Ninety normal sera bound from 0 to 38 per cent. of DNA $(15 \pm 7.96$ per cent.). Sera from 92 patients with JRA bound from 0 to 50 per cent. of DNA (mean $15 \pm 8.7$ per cent.), Sera from forty adults with rheumatoid arthritis bound from 0 to 48 per cent. (mean $18 \pm 12$ per cent.). Mean values were $10 \pm 10$ per cent. for forty patients with progressive systemic sclerosis, $12 \pm 5 \cdot 8$ per cent. for sixty patients with tuberculosis, and $49 \pm 27$ per cent. of DNA for 158 sera from 82 SLE patients (range 0 to 99 per cent.). A binding of more than 50 per cent. of DNA was found only in sera from patients with SLE.

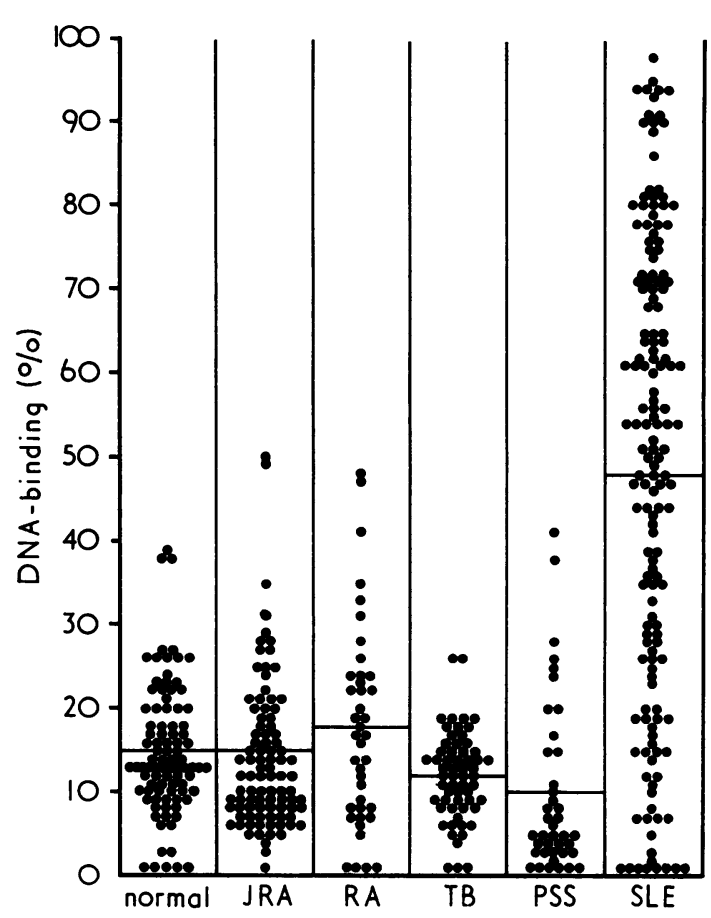

FIG. 1 Percentage of DNA-binding in sera from normal individuals, and patients with JRA, RA, tuberculosis, PSS, and SLE.

PATTERNS OF NUCLEAR FLUORESCENCE The peripheral pattern of nuclear fluorescence was produced by 54 sera from SLE patients.

The diffuse pattern was produced by 167 sera: 86 SLE, 35 RA, 42 JRA, and 5 PSS.

The speckled pattern was produced by 63 sera: 4 RA, 5 SLE, 18 JRA, 27 PSS, and 8 tuberculosis.

A negative indirect fluorescent antibody test was produced by 195 sera: 12 SLE, 1 RA, 32 JRA, 8 PSS, 52 tuberculosis, and 90 normal individuals.

\section{CORRELATION OF PATTERN OF NUCLEAR} FLUORESCENCE WITH DNA-BINDING

The mean DNA-binding of the 54 sera producing a peripheral pattern was $70 \cdot 4 \pm 18 \cdot 2$ per cent. (Fig. 2). Mean values were $32 \cdot 7 \pm 23$ per cent. for 167 sera producing a diffuse pattern, $14 \pm 12 \cdot 2$ per cent. for 63 sera producing a speckled pattern, and $13 \cdot 5 \pm 7 \cdot 9$ per cent. for 195 sera giving a negative ANA test.

CORRELATION OF PATTERN AND

DNA-BINDING IN SLE SERA

The DNA-binding ranged from 28 to 99 per cent. in 


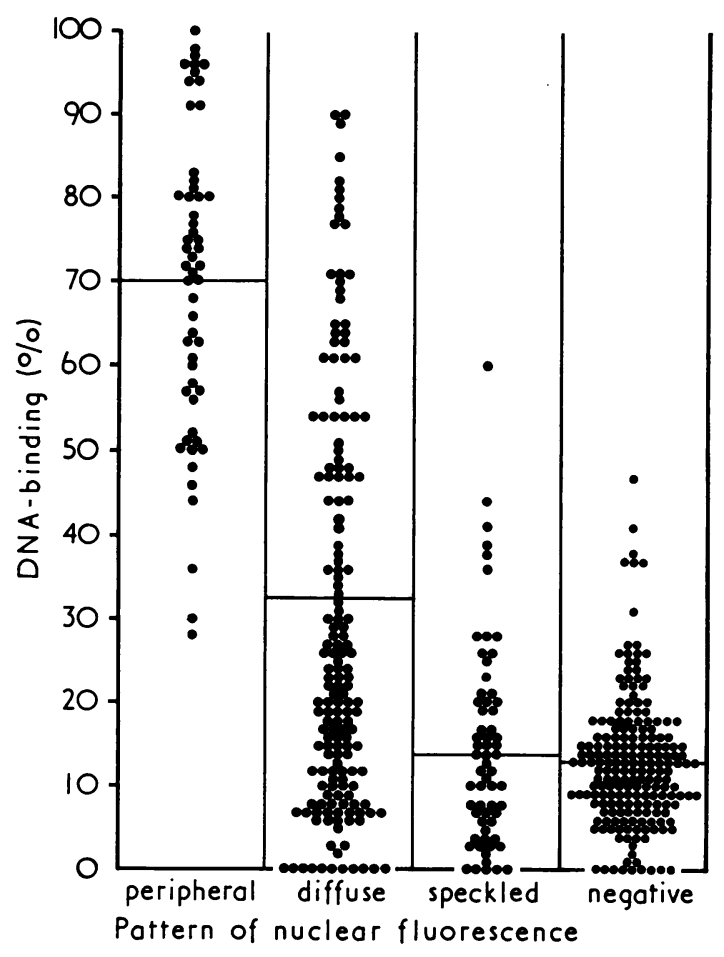

FIG. 2 Relationship between patterns of nuclear fluorescence and percentage of DNA-binding in sera from patients with SLE, RA, JRA, PSS, tuberculosis, and normal individuals.

SLE sera, which produced a peripheral pattern (mean $70 \cdot 4 \pm 18 \cdot 2$ per cent.) (Fig. 3). 87 SLE sera producing a diffuse pattern bound from 0 to 90 per cent. DNA (mean $40 \pm 25.9$ per cent.). The five SLE sera producing a speckled pattern bound from 19 to 61 per cent. DNA (mean $36 \pm 16 \cdot 1$ per cent.). Eleven SLE sera which were negative for antinuclear antibodies bound from 0 to 41 per cent. (mean of $21 \pm 14$ per cent.). It should be noted that these sera were from patients who previously had a positive ANA and a positive LE-cell test but were in prolonged clinical remission at the time serum was obtained for this study.

Of 54 sera producing the peripheral pattern, 45 (83.3 per cent.) bound more than 50 per cent. DNA. Of 86 sera producing the diffuse pattern, $33(38.4$ per cent.) bound more than 50 per cent. DNA.

\section{RELATIONSHIP OF DISEASE ACTIVITY AND DNA-BINDING}

Since none of the normal sera bound more than 40 per cent. DNA, the presence of clinical disease activity in SLE patients was analysed in relation to the presence of DNA-binding of more than 40 per cent. (Table, overleaf).

75 SLE patients had no evidence of clinical disease

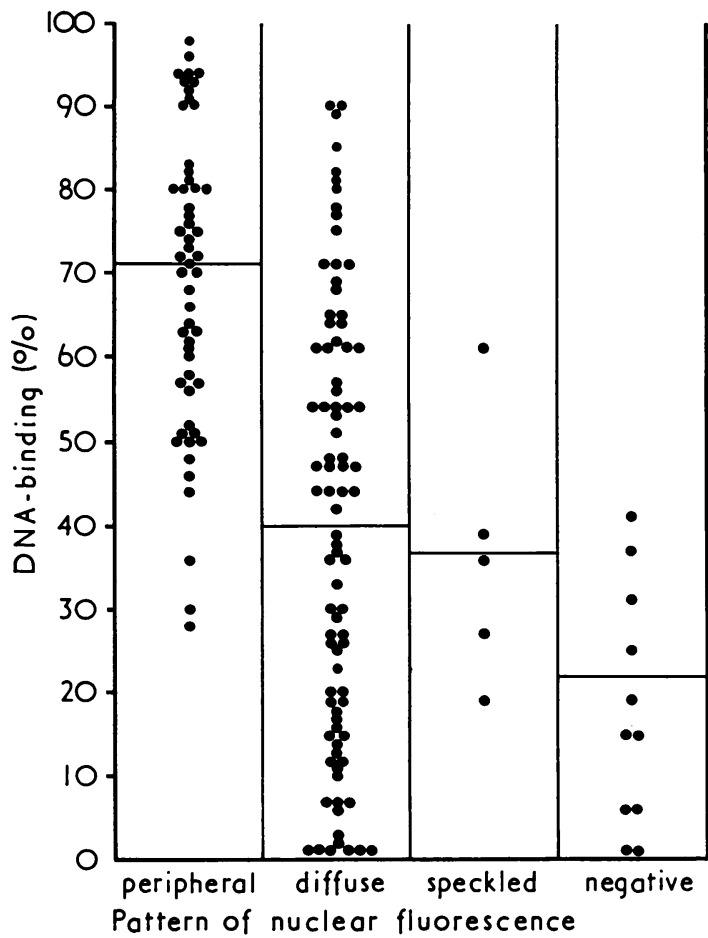

FIG. 3 Relationship between patterns of nuclear fluorescence and percentage of DNA-binding in sera from $S L E$ patients.

activity at the time their serum was obtained. 35 bound more than 40 per cent. of DNA.

61 of 83 sera from patients with clinically active SLE bound more than 40 per cent. of DNA $(P<0.01)$. More striking was the correlation between clinical evidence of active renal disease, i.e. haematuria, increasing proteinuria, increasing renal insufficiency, and a high percentage of DNA-binding. As shown in Table I, of 31 sera from patients with active renal disease, 28 had more than 40 per cent. DNA-binding, whereas 69 of 127 sera from patients with inactive renal disease had more than 40 per cent. $(P<0.0005)$. Less significant correlations of DNA-binding were found for disease activity of joints or of skin.

\section{Discussion}

The results confirm the observations of others regarding the value of measuring DNA antibodies in SLE for both diagnostic and management purposes. DNAbinding of more than 50 per cent. was present only in sera from SLE patients and was not present in sera from 172 patients with other connective tissue diseases or in sera from ninety normal individuals. Of the $\mathbf{3 2 2}$ non-SLE sera studied, none bound more than 50 per cent. DNA, six sera bound between 40 and 50 per 
Table Correlation of DNA-binding and disease activity in patients with SLE

\begin{tabular}{|c|c|c|c|c|c|}
\hline \multirow[t]{2}{*}{ Organ } & \multirow[t]{2}{*}{ Disease activity } & \multirow[t]{2}{*}{ No. of sera } & \multicolumn{3}{|c|}{ DNA-binding activity (per cent.) } \\
\hline & & & $\leqslant 40$ & $>40$ & Significance \\
\hline Any organ & $\begin{array}{l}\text { Present } \\
\text { Absent }\end{array}$ & $\begin{array}{l}83 \\
75\end{array}$ & $\begin{array}{l}22 \\
35\end{array}$ & $\begin{array}{l}61 \\
40\end{array}$ & $\mathrm{P}<0.01$ \\
\hline Kidneys & $\begin{array}{l}\text { Present } \\
\text { Absent }\end{array}$ & $\begin{array}{r}31 \\
127\end{array}$ & $\begin{array}{r}3 \\
58\end{array}$ & $\begin{array}{l}28 \\
69\end{array}$ & $P<0.0005$ \\
\hline Joints & $\begin{array}{l}\text { Present } \\
\text { Absent }\end{array}$ & $\begin{array}{r}39 \\
119\end{array}$ & $\begin{array}{r}9 \\
52\end{array}$ & $\begin{array}{l}30 \\
67\end{array}$ & $\mathrm{P}<0.025$ \\
\hline Skin & $\begin{array}{l}\text { Present } \\
\text { Absent }\end{array}$ & $\begin{array}{r}40 \\
118\end{array}$ & $\begin{array}{l}10 \\
52\end{array}$ & $\begin{array}{l}30 \\
66\end{array}$ & $\mathrm{P}<0.05$ \\
\hline
\end{tabular}

cent. DNA, and ten sera bound between 30 and 39 per cent. DNA.

Hasselbacher and LeRoy (1972) reported findings similar to those described here. These investigators also used bacterial DNA and found that the mean DNA-binding in the sera of forty normal subjects was $18.7 \pm 8.6$ per cent. In our study, sera from ninety normal individuals were tested and the mean DNAbinding was $15 \pm 7.96$ per cent. Thus, the use of bacterial DNA seems to lead to a somewhat higher DNA-binding in normal sera than that reported for mammalian DNA.

Previous reports have shown a lower DNA-binding for non-SLE sera (Pincus and others, 1969; Hughes and others, 1971; Carr and others, 1969). This difference may also be related to the source of DNA, since these investigators have used calf thymus DNA or a human tumour cell line DNA.

The peripheral pattern was present only in sera from patients with SLE. Thus, both the peripheral pattern of nuclear fluorescence and a high DNA-binding are limited to sera from patients with SLE. When the two methods are compared, it becomes clear that a high DNA-binding is present in more SLE sera than produce the peripheral pattern. A high DNA-binding was present in 83 per cent. of sera producing the peripheral pattern and in 38 per cent. of SLE sera producing the diffuse pattern. The diffuse pattern was produced by sera from patients with a variety of connective tissue diseases. Of the sera producing a diffuse pattern, only those from SLE patients bound more than 50 per cent. DNA. Thus, the presence of a high DNA-binding was a more sensitive indicator than the presence of the peripheral pattern in detecting patients with SLE.

\section{Summary}

The pattern of nuclear fluorescence produced by undiluted patients' serum using fluorescein-conjugated anti-IgG was compared with the percentage of DNA-binding by the same serum using the Farr technique. The data reveal that nearly all sera producing a peripheral pattern have a high DNA-binding activity, whereas sera producing a diffuse pattern may or may not have a high DNA-binding activity. High DNA-binding activity and the peripheral pattern both occur only in sera from patients with SLE.

We should like to thank Mrs. Ann Bettencourt and Mrs. Sigita Wallace for technical assistance and Miss Marilyn Leach for secretarial assistance. Dr. John Foulds of the Department of Microbiology was of great help in preparing the radiolabelled DNA and in reviewing the manuscript.

\section{References}

Cammarata, R. J., Rodnan, G. P., And Fennell, R. H. (1967) J. Amer. med. Ass., 199, 455 (Serum anti- $\gamma$-globulin and ANF in the aged)

Carr, R. I., Koffler, D., Agnello, V., ANd Kunkel, H. G. (1969) Clin. exp. Immunol., 4, 527 (Studies on DNA antibodies using DNA labelled with actinomycin-D $\left({ }^{3} \mathrm{H}\right)$ or dimethyl $\left({ }^{3} \mathrm{H}\right)$ sulphate)

Casals, S. P., Friou, G. J., and Teague, P. O. (1963) J. Lab. clin. Med., 62, 625 (Specific nuclear reaction pattern of antibody to DNA in lupus erythematosus sera)

Ceppellini, R., Polli, E., ANd Celada, F. (1957) Proc. Soc. exp. Biol. (N.Y.), 96, 572 (A DNA-reacting factor in serum of a patient with lupus erythematosus diffusus)

Cohen, A. S., Reynolds, W. E., Franklin, E. C., Kulka, J. P., Ropes, M. W., Shulman, L. E., and Wallace, S. L. (1971) Bull. rheum. Dis., 21, 643 (Preliminary criteria for the classification of systemic lupus erythematosus)

Friou, G. J., FINCH, S. C., AND DETRE, K. D. (1958) J. Immunol., 80, 324 (Interaction of nuclei and globulin from lupus erythematosus serum demonstrated with fluorescent antibody) 
GonZalez, E. N., AND Rothfield, N. F. (1966) New Engl. J. Med., 274, 1333 (Immunoglobulin class and pattern of nuclear fluorescence in systemic lupus erythematosus)

Hasselbacher, P., AND LeRoy, E. C. (1972) Arthr. and Rheum., 15, 113 (Antibodies to native DNA in SLE, non-SLE and normal human sera. Abstr.)

Hughes, G. D., AND Rothfield, N. F. (1970) Conn. Med., 34, 171 (Serum antinuclear antibodies in rheumatoid arthritis)

Hughes, G. R. V., Cohen, S. A., and Christian, C. L. (1971) Ann. rheum. Dis., 30, 259 (Anti-DNA activity in systemic lupus erythematosus)

Pincus, T., Schur, P. H., Rose, J. A., Decker, J. L., and Talal, N. (1969) New Engl. J. Med., 281, 701 (Measurement of serum DNA-binding activity in systemic lupus erythematosus)

Robbins, W. C., Holman, H. R., Deicher, H., and Kunkel, H. G. (1957) Proc. Soc. exp. Biol. (N. Y.), 96, 575 (Complement fixation with cell nuclei and DNA in lupus erythematosus)

Rothfield, N. F., AND Rodnan, G. P. (1968) Arthr. and Rheum., 11, 607 (Serum antinuclear antibodies in progressive systemic sclerosis (scleroderma))

- AND Stollar, B. D. (1967) J. clin. Invest., 46, 1785 (The relation of immunoglobulin class, pattern of antinuclear antibody, and complement-fixing antibodies to DNA in sera from patients with systemic lupus erythematosus)

Seligmann, M. (1957) C.R. Acad. Sci.(Paris), 245, 343 (Mise en évidence dans le sérum des malades atteints de lupus érythémateux disseminé d'une substance déterminant une réaction de précipitation avec l'acide desoxyribonucléique)

Wold, R. T., Young, F. E., TAN, E. M., AND FARR, R. S. (1968) Science, 161, 806 (Deoxyribonucleic acid antibody: a method to detect its primary interaction with deoxyribonucleic acid) 